\title{
Rwanda, Burundi, and Their "Ethnic" Conflicts
}

\section{Stephen B. Isabirye and Kooros M. Mahmoudi \\ Northern Arizona University.}

This paper demonstrably dispels the assumption that ethnic conflict in Rwanda and Burundi is a chronic endemic phenomenon. It emphasizes the consolidation of the caste system during the colonial era, intra regional disparities within the two communities, high population densities, very weak economic bases, poverty, and international interference as some of the cardinal dynamics behind the current deadly contentions within the two states. An analysis behind the genocidal tendencies in the two countries is well illustrated, with special emphasis on the Rwandese tragedy of 1994 as well as its parallels and divergences with the Nazi Holocaust.

The reason for writing this paper was inspired by a question in the African History Affairs Paper at the Advanced School Certificate level by the now defunct East African Examinations Council in 1976, which asked why Rwanda and Burundi had frequently fallen prey to "tribal" wars. It is quite obvious that the situation in Rwanda and Burundi in 1976 was by any stretch of imagination "more tame" than the one in 1996. Nevertheless this examination question of 1976 was timely in that by that year Rwanda had experienced its first fully-fledged post colo- 
nial military coup that had taken place in 1973, while Burundi had undergone its first mass scale pogroms directed against the majority-Hutu population, which had left up to 250,000 of them dead in 1972.

Upon reflection the events that have taken place in both countries since 1976 may make it easier in answering this germane question to the ongoing conflict between the so-called "two distinct ethnic groups," notably the Tutsi and Hutu. Why should we concern ourselves with "ethnic" conflicts in Rwanda and Burundi; after all, have not countries such as Uganda, Somalia, Angola, Mozambique, Liberia, Sierra Leone and many others undergone similar traumas in their post colonial history?

The "ethnic" conflicts in Rwanda and Burundi, however tragic they may seem, are very interesting to analyze, because the two ethnic groups in both countries have virtually identical culture, language, names, religions and so forth, in addition to having almost the same percentage composition of the two groups in both countries, whereby the Hutu are the majority, while the Tutsi are a minority. ${ }^{1}$ Both countries have negligible small percentages of the Twa, Asians. and Europeans.

Various studies, such as those of Rene Lemarchand, Jacques Maquet, Van den Berghe, and Warren Weinstein have continued to base their reasons for ethnic strife in the two countries on countenances such as language barriers in the two countries, skin pigmentation, cultural characteristics and modes of productivity. These schools of thought base their assumptions on factors that militate against well-established ethnic boundaries.

Before we proceed with discussing the conflicts in Rwanda and Burundi, we need to elucidate on the terms, "ethnic solidarity" and "ethnic collectivization." "Ethnic solidarity" is defined as the strength or density of ethnic social interaction. Exploited ethnic populations do not automatically organize as cultural groups, although dispossessed and socioeconomically "assimilated" ethnic populations do on occasions correlate as "ethnics." This can be demonstrated within the Hutu-Tutsi dichotomy, which until the last century did not produce clearly delineated boundaries of ethnicity vis-a-vis competition for resources. This was because until the emergence of the colo- 
nial regime and the subsequent capitalist system, pre colonial Rwanda and Burundi were not societies based on economic class distinctions. It is within this context that we need to look at "ethnic enclaves." An ethnic enclave is a structure in which members of an ethnic population exploit an occupational niche, participate in common ethnic institutions and organizations as well as the formation of a very dense interaction of network communication, socialization, and marital endogamy. Consideration of the organizational base of ethnic enclaves presupposes that two types of boundaries are relevant. One set of boundaries is drawn around cultural markers, where typical criteria for membership are language, nationality, or other common characteristics. The second set of boundaries is drawn around productive activities, defined by occupations, sectors of the economy, or industry. When the two boundaries coincide considerably, ethnic solidarity is doubly reinforced and maintained by economic links that are also familial and personal (Olzak 20-1).

In pre colonial times this unequal relationship in both kingdoms was maintained through an ethos of ethnic superiority and the pervasive system of social and economic contracts that provided payoffs for most members of the society (Kuper 54). The two groups have often been stereotyped as follows: the Tutsi are predominantly cattle herders, while the Hutu are basically peasants. However this characterization oversimplifies the roles of the two groups. In fact many Hutu owned large herds of cattle, while many Tutsi were agriculturists. It was common for anyone that owned a lot of cattle, even "physiologically" resembling a Hutu to be labeled, "Tutsi," while the poor agricultural peasants, regardless of their Tutsi or Hutu caste origins, were classified as "Hutu."

Although both Rwanda and Burundi began as monarchical states the two kingdoms differed from each other. For example, in Burundi the kingdom did not develop strong unitary features as was the case with Rwanda. In Burundi the king did not have as much supreme power over the Tutsi chiefs as was the case with Rwanda. The despotic character of the Kinyarwanda monarchy was nowhere more evident than in its bureaucratization of subordinate political roles and the precarious tenure of its occupants. The political system was one in which a triple 
hierarchy of army chiefs, land chiefs, and cattle chiefs were all recruited from the dominant stratum whose powers radiated from the provinces to the districts. Each province was entrusted to an army chief and each district to a land chief (who was also the cattle chief) who was responsible for the collection of tithes in produce and cattle. The powers of the chiefs were dependent on the blessings of the Mwami (king). Indeed we can confidently suggest that they were "bureaucrats" in a sense that they did not claim their position by right or inheritance or by virtue of any prior connection with the area to which they were appointed. In contrast Burundi looked like a cluster of warring principalities. The king's absolute powers were at best very superficial in that the Baganwa (royal chiefs) were the actual power behind the throne. ${ }^{4}$ In both kingdoms, the ties of client ships ran like a seamless tenure of its occupants, linking men and women in a relationship of mutual dependence (Lemarchand 26-8). In fact, there has been speculation that at the time of colonial contact the Tutsi and Hutu were on the way to resembling a sub-homogenous ethnic entity. What German and subsequent Belgian colonial rule did was to reverse this process of amalgamation through the pre-existing system of kingship into a "neo-feudal" state, founded on a rigid dichotomy between "Tutsi lords" and "Hutu serfs," which in turn lent legitimacy to an imaginary distinction between a so-called superior race of immigrant "Hamites" of either Egyptian or Ethiopian origins (Tutsi) and the so-called "primitive indigenous Negroes" (Hutu and Twa). 6

In a summation the German colonial era in Rwanda and Burundi could be epitomized in three phases: (i) from 1899 to 1903 as a period of "non-intervention," although interrupted in 1903 when German military expeditions were launched against insubordinate chiefs, (ii) 1903 to 1908 as the period of consolidation in which German colonial rule firmly established itself in the two territories through the curtailment of the powers of the chiefs; while the (iii) 1908-1915 period was an era of "Divide and Rule" in which the monarchies in the two colonies were prevented from gaining a permanent ascendancy over the chiefs and vice-versa.

German rule in Rwanda and Burundi was terminated with the end of World War I when all its colonies were taken over by 
other European powers, first, under the League of Nations and later as the United Nations (U.N.) Trusteeship. By 1918, the Belgians who were prominent in the region had managed to drive the Germans out of the Ruanda-Urundi colony.

Belgian colonial rule in Ruanda-Urundi in a way resembled British "indirect rule," for with the assistance of the colonial government, the two Tutsi kings in this joint colonial kingdom consolidated their rule in the region. Although domestic slavery was abolished in 1923, the kings in both territories claimed not only "ownership" of the land, but also the Hutu who tilled it, thus reducing them to a form of a landless peasantry.

During the early colonial era, the Belgian authorities compelled every chief as well as sub-chiefs to enforce mandatory coffee-growing, which was to result in the reduction in the amount of arable land available for food cultivation. The Ruanda-Urundi colony also became a labor reserve for the Belgian Congo, especially for the mines of Katanga. These Belgian colonial policies resulted in the emigration of Banyarwanda and Barundi from their colonies to others such as Uganda in search of better living conditions.

In the late 1950s, in spite of the "winds of change" that were sweeping Africa, the Belgian authorities clung to an image of an ethnic state dominated by the Tutsi monarchies. In their attacks on African nationalism, they encouraged ethnic loyalties as a means of fragmenting an emerging African opposition to colonial rule. It is in this realm that the Hutu educated elite became the vanguard of the nationalist movement.

Unlike Rwanda, Burundi's colonial experience was relatively brief, but it had a significant impact on the colony's development. Initially, the Belgians had attempted to administer Burundi through what it considered to be the kingdom's "traditional political structure." Operating under the mistaken assumption that the Tutsi domination of the political system was as strong as in Rwanda, the Belgians gave preponderant power and educational opportunities to the Tutsi. In this context, Belgian favoritism of the Tutsi consolidated their political dominance. Despite efforts in the 1950 s by the colonial authorities to democratize its administration under the Trusteeship Agreement with the United Nations, it did little to alter Tutsi political domination. 
The spread of Western education as well as its emphasis on notions such as Democracy and Equality inspired many Hutu, especially in light of the underdog's status of their ethnic group, however, not before it had created separate political enclaves within the two ethnic groups. As in Rwanda, the Tutsi dominated the political and economic echelons, while the Hutu eventually came to dominate the educational sector in colonial Burundi.

This was the situation in both countries at the time of their Independence on July 1, 1962. While recent analysis of the Hutu-Tutsi conflict is often seen in purely ethnic lenses, little attempts have been employed to look at the difference within the two ethnic groups. For example, in Rwanda, there were differences between the southern Hutu and their northern counterparts. For instance, the first President of Rwanda, Gregoire Kayibanda was a southern Hutu. The 1973 military coup which brought General Juvenile Habyarimana was seen as an attempt by the northern Hutu to dominate their southern correlates. In a similar manner, the Tutsi were divided amongst the Tutsi-Banyaruguru, who thought of themselves as being superior to the Tutsi-Hima. Consequently, a situation was created where regional difference affected and complicated the pattern of ethnic group relations as a result of these subunits within each society.

In Rwanda, independence created a new and ambiguous situation. The political system became inverted, with a small Hutu elite dominating the political power structure. Many of the hundreds of thousands of Tutsi who remained after the 1959 revolution (that ended the centuries- old Tutsi domination in the country) were wealthy and educated. In order to contain their influence, the new ruling Hutu elite developed a policy of systematic discrimination, especially in arenas that permitted upward mobility, namely modern education, jobs, and politics. So a quota system was installed that limited Tutsi access to higher education as well as state jobs. The post colonial regime in Rwanda even retained the Identity Card policy (which has since been formally abolished by the current Rwandese Patriotic Front [RPF] government) that had been introduced by the colonial authorities as a way of identifying Africans by their ethnic origins (the Tutsi had been the main beneficiaries of this 


\section{Ethnic Studies Review Volume 23}

practice because of their social status in society during the colonial era). In addition to identifying one's ethnicity, the government also forbade the return of more than 100,000 Tutsi refugees under the pretext that there was no more room for them in the country.

As far as Burundi's post colonial history is concerned there have been marked efforts on the part of Tutsi factions to strengthen their control over the state and armed forces and to transform them into increasingly effective agents for the perpetuation and expansion of Tutsi hegemony over all aspects of Burundian society. There have been repeated attempts by Hutu factions, usually in the form of abortive coups or uncoordinated uprisings, to combat these Tutsi efforts. It is this conflict that has given rise to the various ounds of political and ethnic violence which Burundi has witnessed since Independence. The first major round of post colonial violence occurred between 1965 and 1966 when an abortive coup by Hutu military officers met with violent suppression by Tutsi forces. This led to the purging of numerous Hutu army officers and the execution of thousands of Hutu, including virtually every significant Hutu leader in Burundi. The Hutu-Hima-led government again carried out another bloody purge of the Hutu when another Hutu-led coup attempt was foiled in 1969.

The violence that broke out in 1972 represented a dramatic escalation of the conflict. In the wake of deepening intraTutsi tensions and increasing anti-Hutu provocation by local Tutsi officials, Hutu uprisings broke out in the capital and parts of the countryside. These uprisings, which were assisted by Zairean troops and Hutu refugees based in Tanzania, were quickly crushed by the armed forces. The insecure Tutsi-Hima regime in Bujumbura, however, used the opportunity to embark on a widespread and brutal slaughter not only of the rebels but also of almost the entire Hutu as well as rival Tutsi elite. Aided by Tutsi civilians and youth militias, the army is estimated to have massacred up to 250,000 Hutu and to have driven an estimated 150,000 of them out of the country (Abrams 37, 14748). The events of 1972 consolidated Tutsi political, social and economic hegemony in Burundi and left the Hutu community traumatized and leaderless for quite sometime.

The violence that broke out in 1972 represented a dra- 
matic escalation of the conflict. In the wake of deepening intraTutsi tensions and increasing anti-Hutu provocation by local Tutsi officials, Hutu uprisings broke out in the capital and parts of the countryside. These uprisings, which were assisted by Zairean troops and Hutu refugees based in Tanzania, were quickly crushed by the armed forces. The insecure Tutsi-Hima regime in Bujumbura, however, used the opportunity to embark on a widespread and brutal slaughter not only of the rebels but also of almost the entire Hutu as well as rival Tutsi elite. Aided by Tutsi civilians and youth militias, the army is estimated to have massacred up to 250,000 Hutu and to have driven an estimated 150,000 of them out of the country (Abrams 37, 14748). The events of 1972 consolidated Tutsi political, social and economic hegemony in Burundi and left the Hutu community traumatized and leaderless for quite sometime.

The 1972 Burundi massacres and the subsequent flight of Hutu refugees was the chief catalyst for the military coup of 1973 in neighboring Rwanda. Then Defence Minister, General Juvenal Habyarimana, a northern Hutu from Gisenyi justified the coup d' etat by arguing that the 'PARMEHUTU government of Gregoire Kayibanda was unable to protect the Hutu from a possible Tutsi political resurgence in the country.

At first the Habyarimana regime achieved much in the economic arena in the 1970s and 1980s: infrastructure and housing underwent great improvement; the civil service was modernized, and a new clean water supply system was installed in the country. His government policies attracted foreign aid, although much of it was spent on ill-advised insecure and short-sighted projects which were at times imposed by the aid donors.

As a result of such factors the mid 1980s saw an increase in poverty. A decade-lon decline in coifee prices, the country's major export, paralleled the devaluation of the Rwandese franc by forty percent in 1989. Coffee exports fell from $\$ 144$ million in 1985 to $\$ 30$ million in 1993. Aggregate GDP per capita decreased from $\$ 355$ in 1983 to $\$ 260$ in 1990. These declines substantially reduced the earnings of the state as well as the purchasing power of most rural households. In urban areas, wage stagnation and a dearth in employment opportunities was accompanied by a rise in food prices. Faced with such 
mounting economic crisis, as well as increasing dependence on foreign finance, the Habyarimana regime saw no alternative but to accept an International Monetary Fund (IMF) Structural Program, that would freeze government salaries and devalue the Rwandese franc by sixty-seven percent (Uvin 11).

The Rwanda of the 1990s has been associated with genocidal disposition. Before we discuss the events of 1990s, we need to define and conceptualize the word, "genocide."

Contrary to the international media's assertion at the time of the Rwandese Genocide, the Hutu-Tutsi conflict is not an "age long" discord. Oral as well as written historical accounts do not support this assertion. Although the Tutsi overlords had exercised political hegemony over the Hutu for generations, which may have created a few tensions between the two, both groups had coexisted with each other through intermarriage.

Since issues of contention tend to be conducive to genocidal conflict in places such as Rwanda and Burundi, a small minor fray, for example, could easily set a chain of reactions such as reciprocal terrorism as well as political confrontation at the national level. This was the case in Burundi in 1988 when clashes between the Tutsi -dominated UPRONA party local officials and Hutu peasants over spoils from illicit coffee smuggling into Rwanda led to a bloody confrontation in northern Burundi in which about 500 Tutsi are known to have perished. Under the pretext of trying to restore "law and order" the Tutsicontrolled Burundi army moved in, inflicting a series of massacres, resulting in about 20,000 Hutu deaths and driving tens of thousands of them into exile in neighboring Rwanda, (Abrams 148; Dorwood 34). Burundi and Rwanda are therefore classic examples whereby a long history of protracted struggle, violent repression and its resultant memories for subordinate groups of past injustice and atrocity are most likely to translate such emotional impulses into destructive violence. *

At the beginning of the 1990s three striking factors con-

"A country such as Uganda has also had some conflicts that in fact resemble genocidal predispositions. These include the pogroms against the Langi and Acholi in the early 1970s, the Kakwa and Lugbara in the late 1970s and early 1980s. However, Ugandan leaders have not always sought the RwandeseBurundian type of genocide because of Uganda's more heterogenous and very autonomous ethnic configuration. 
fronted the Habyarimana government in Rwanda, emanating mainly from the disgruntled Hutu elite. The regime had adopted increasingly harsh measures against its political opponents through ruthless means such as politically-motivated assassinations. Political opposition came mostly from the south and central regions, since most positions of power in the government were monopolized by people from the President's district in the north, which had also received a lion's share in public spending investment. Widespread corruption, geographical exclusion and disappointment, coupled with the slow pace of development (especially after the Structural Adjustment Program had reduced the efficiency of the state) fueled this discontent.

Another cardinal problem the Habyarimana government faced was the refugee problem, especially that of the Tutsi Diaspora that had fled the 1959 Revolution. The government's reluctance to permit these refugees back was in itself a problem. This had to do with Tutsi lands that had been confiscated by the Hutu- administrations. In this regards the government was very apprehensive of returning these refugees home lest they started claiming property such as land that had previously been seized during the 1959 tumult. Nonetheless, since the Tutsi diaspora in places such as Uganda faced consistent resentment and persecution in their host countries, the only alternative was to return to Rwanda by any means necessary. It is against this background that on October 1, 1990, the Tutsi refugees in Uganda (who had also been active in the country's Uganda National Resistance Army [NRA] during the 1980s civil war in that country), decided to invade Rwanda en masse under the newly reconstituted Rwandese Patriotic Front (RPF'). It is noteworthy that this had not been the first time that Tutsi refugees had launched invasions from neighboring countries after Independence, for they had impelled abortive ones from Burundi and Uganda between 1963 and 1964 as we have already noted. Yet, the 1990 invasion appears to have been better coordinated, taking into account the fact that many of the Tutsi fighters had acquired experience as military combatants in Uganda's NRA. The Rwandese government retaliated by detaining around 9000 Tutsi while massacring around 2000 of them. For the time being the Tutsi invasion united the southern, 
central and northern Hutu who saw the invasion as a serious threat to Hutu political dominance. Despite this apparent display of unity the RPF' invasion proved to be very formidable.

In response to the "RPF' menace" the ruling Hutu authorities began contemplating genocide as the most viable solution to the Tutsi threat. In 1992, two death squads were formed by the names of Interahamwe (those who attack together) and Impuzamugambi (those with a single purpose"). The civil war went on unabated with atrocities committed by both sides. Despite the Arusha Peace Accord between the two antagonistic forces on August 4, 1993, the bloodletting between the two sides continued with undiminished ferocity. The assassination of the Hutu President, Melchior Ndadaye, in neighboring Burundi increased the urge for genocide against the Tutsi as well as the Hutu opposition.

So on April 6, 1994, when the plane carrying President Habyarimana as well as President Cyprian Ntaryamira of Burundi was mysteriously shot down over Kigali after their return from a second round of Arusha Peace Talks, the instruments of genocide that had been years in the making were implemented. The Rwandese Genocide has often been compared to the Jewish Holocaust under the Nazis. There are similarities as well as differences between the two. Like the Germans and Jews, the Hutu and Tutsi had lived together for half a millennium. However, unlike the German Jews and the Germans "Proper", the Hutu and Tutsi were far more intertwined with each other in political, cultural, social and economic terms. This probably made it easier for the Hutu extremists to carry out their form of genocide with more speed than had their Nazi predecessors, which explains why they could have managed to kill more than a million people in just three months. Mobilizing thousands of Rwandese to slaughter tens of thousands of their own required effective organization. Unlike other African "failed states" the Rwandese state had been successful in maintaining political as well as relative economic stability until 1990 when the current upheavals commenced. It was not until July, 1994, when the Tutsi-led RPF' seized power in Rwanda, that the genocide was halted. Just as the Holocaust redefined Jewish identity, the Rwandese Genocide has left a profound impact on the psyches of both Tutsi and Hutu. 
While these events were unfolding in Rwanda, Burundi was also moving, but at a much slower pace, towards its own genocidal agenda. Although it is possible to argue that polarization in Rwanda and its fearful expressions were intimately related to the process of polarization in Burundi, the social appendages as well as the infrastructure of group relations were very different from those of Rwanda and seemed to offer real possibilities for national integration, but in the end, an even more massive holocaust seemed to await the Hutu majority (as opposed to the Tutsi minority in Rwanda) in Burundi. We have already looked at the Hutu pogroms of 1972 and 1988. As a result of international outcry and condemnation of the 1988 bloodbath, the Tutsi-led military government of Major Pierre Buyoya (who had seized power in September 1987) was compelled to initiate political reforms that would usher in the first democratically-elected government in Burundi in June 1993 under President Melchior Ndadaye, a Hutu, however hopes for everlasting peace were dashed when Ndadaye was assassinated by hardline Tutsi elements within the army on October 21, 1993, resurrecting Hutu-Tutsi' acrimony in the country. The two succeeding Hutu Presidents, Cyprian Ntaryamira (who died in the same plane crush as the Rwandese President in 1994) and Sylvestre Ntibantuganya, could neither control the unruly Tutsi-led army nor the Hutu guerilla rebel militias. This prompted Major Pierre Buyoya to stage his second military coup on July 25,1996 . The reaction to this coup was very swift: many surrounding countries imposed economic sanctions on the new regime. However they do not seem to have weakened Buyoya and his "mono ethnic" Tutsi-led army's rein on power. Meanwhile the Hutu guerilla militias have intensified their struggle with the government and by February 1998 the war was being fought on the outskirts of the capital city, Bujumbura, creating about 350,000 internal refugees as of March 2000 (Nutt). Nevertheless, as of this writing, the situation in Burundi remains very fluid, and there are still fears that the country could degenerate into the same genocidal holocaust as that in Rwanda.

In assessing the conflict in the two countries we may ask ourselves what the solutions will be to the current "tribal warfare" in the two states. The answers are not that easy to come 
across. One proposition has been the partition of Rwanda and Burundi, whereby one country is awarded to the Hutu while the other one goes to the Tutsi. This type of denouement is impractical for the simple reason that the Hutu and Tutsi have been living in these two interlocking entities for generations, and neither of the two ethnic groups would be willing to relocate from their ancestral lands. Partition is not often the best solution for the simple reason that animosities between the two groups could intensify and crystallize hard feelings on both sides, if the Indian subcontinent Partition of 1947 and 1948 is any indication of an outcome.

The other problem that has been one of the key reasons behind the intensification of ethnic animosities within the two countries has been poverty as well as dense population in the two countries. At the time of the Rwandese Genocide of 1994 Rwanda was the fifteenth poorest country in the world while Burundi was the eighth according to World Bank statistics, (International Bank)

Indices since then suggest that the economic situation has deteriorated as a result of the ongoing civil strife in both countries. Land is a very important problem in Rwanda and Burundi. For example Rwanda is the most densely populated country in Africa. Each square kilometer of agricultural land supports more than 400 people. Eighty-five percent of the people live beneath the poverty line, and a third of the children suffer from malnutrition. There is no doubt that the war and the subsequent genocide, resulting in massive loss of life and population have only aggravated this problem. As a result, agricultural production in 1995-96 was only sixty-six percent of the 1990 level while in 1996-1997 it was still only seventy-eight percent. Population displacement in general has resulted in de-capitalization, due to lack of maintenance of terraces as well as a decline in soil fertility, due to lack of investments and deconstruction as a result of poor credit availability. The composition of production units has also changed, with a sixty-one percent increase in the number of female-headed households (from twenty-one percent of the total in 1992 to thirty-four percent in 1996) and a twenty-five percent reduction of males between the ages of fifteen and sixty-four over the 1990-1996 period (Massacring 24-7; Van Hoyweghen 357). 
The Hutu-Tutsi conflict in the two countries is likely to have regional as well as international ramifications. A country such as Uganda as we have already noted has been sucked into the conflict by virtue of having had numerous Rwandese refugees over the decades. It is imperitive to note that the Hutu-Yutsi conflict in the two countries spilled into the Congolese civil strife of 1996 and 1997, because the Banyamulenge ethnic group, which was on the verge of being politically and economically disenfranchised by the crumbling Mobutu regime, is ethnically affiliated to Tutsi. In a show of ethnic solidarity the current Tutsi-led governments in the two countries decided to back their brethren in their struggle against then Zairean government but not before inflicting severe retributions on the Hutu refugees that had fled Rwanda after the 1994 Genocide. Therefore what began as a Hutu-Tutsi conflict in the two countries eventually turned into a nationwide rebellion in neighboring Congo (formerly Zaire) causing the collapse of the longtime Mobutu regime.

There is no doubt that there will be an attempt to bring the perpetrators of genocide in Rwanda as well as in Burundi to justice. However, this aspect misses the point of trying to redress the historical, political, and economic root causes of this bloody feud, many of which this paper has sought to address.

There is no outright win-win situation in this conflict. A negotiated settlement between the two adversaries that should involve the surrounding regional countries (which have been taking sides in this crisis for a very long time) is the only panacea to this seemingly internecine disharmony.

\section{Endnotes}

1 Jason S. Abrams, "Burundi: Anatomy of an Ethnic Conflict," Survival (1995), 37, 147-148.

2 Abrams, "Burundi: Anatomy of an Ethnic Conflict," 148., David Dorward, "Rwanda and Burundi: The Politics of Ethnicity and the Psychology of Victimization," Current Affairs Bulletin 37 (1994), 34.

3)Http://www.ipass.net/geo/hamradio/af/9x.htm., Http://www.earlham.edu/www/pol.sci/globalprobs/rwanda/HISTORY.htm1.,Http://ww w.info.usaid.gov/HORN/burundi/misc/burfact.htm1 


\section{Ethnic Studies Review Volume 23}

4 International Bank for Reconstruction and Development. World Bank: Development 1994: Infrastructure for Development. Washington, D.C.: Oxford University Press, 1994, 154-156.

5 Leo Kuper, "Theories of Revolution and Race Relations," in Donald E. Gelfand and Russell d. Lee, eds, Ethnic Conflicts and Power: A Cross-National Perspective (New York: John Wiley Sons, 1973), 54.

6 Rene Lemarchand, (London: Pall Mall, 1970), 26-28.

7 Ibid., 36.

8 Ibid., 47.

9 "Massacring the Truth in Rwanda", Living Marxism (December 1995), 24-27., Saskia Van Hoyweghen, "The Urgency of Land and Agrarian Reform in Rwanda," -African Affairs 98 (July 1999), 357.

10 Dominic Nutt, "The Terror That is Burundi's Regroupment Camps." All Africa News Agency (March 3, 2000).

11 Susan Olzak, "A Competition Model of Ethnic Collective Action in American Cities, 1877-1889, in Susan Olzak and Joane Nagel, eds, Competitive Ethnic Relations (New York: Academic Press, 1986), 2021.

12 Peter Uvin, "Tragedy in Rwanda: The Political Ecology of Conflict," Environment 38 (April

1996), 11., "The roots of crisis: race, caste and violence in Rwanda," Http://kanga.ifrc.org/utv/main1.htm1.

\section{Bibliography}

Abrams, Jason S. "Burundi: Anatomy of an Ethnic Conflict." Survival 37 (Spring 1995), 144-164.

Adelman, Howard and Astri Suhrke. The Path of Genocide: The Rwanda Crisis from Uganda to Zaire. New Brunswick/London: Transaction Publishers, 1999.

American Broadcasting Company, Nightline April 6, 1998. 
Isabirye/Mahmoudi-Conflicts

Amnesty International. Burundi:Refugees forced back to danger."Http://www.amnesty.it/ailib/aipub/1996/SUM/11603496. htm.

Barnett, Michael. "UN Security Council, Indifference and Genocide in Rwanda." Cultural Anthropology 12 (November 1997), 551-578

Briscoe-Wilson, Elizabeth. "Rwanda and Uganda: Contrasting Images." Sage 9 (Summer 1995), 65-71.

Chretien, Jean-Pierre. "Burundi Social Sciences Facing Ethnic Violence" Issue 19 (1990), 38-40.

Dahrendorf, Ralf. Class and Class Conflict in Industrial Society. Stanford: Stanford University Press, 1959.

Davidson, Basil. The Black Man's Burden: Africa and the Curse of the Nation-State. New York: Random House, 1992.

Destexhe, Alain. Rwanda and Genocide in the Twentieth Century. New York: New York University Press, 1995.

Dorward, David. "Rwanda and Burundi: The Politics of Ethnicity and the Psychology of Victimization." Current Affairs Bulletin 71 (1994), 31-38.

Gelfand, Donald E. and Russell D. Lee. Ethnic Conflicts and Power: A Cross-National Perspective. New York: John Wiley and Sons, 1973.

Gurr, Ted Robert and Barbara Harff. Ethnic Conflict in World Politics. Boulder/San Francisco/Oxford: Westview Press, 1994.

Hardjono, Ratih. "The Tragedy of Rwanda and Burundi." Nieman Reports 50 (Spring 1996), 68.

Hoyweghen, Saskia van. "The Urgency of Land and Agrarian Reform in Rwanda." African Affairs 98 (July 1999), 353-372.

Huliaras, Asteris C. "The 'Anglosaxon Conspiracy': French Perceptions of the Great Lakes Crisis" The Journal of Modern African Studies 36 (December 1998), 593-609

Human Rights Watch. Slaughter among Neighbors: Political Origins of Communal Violence. New York: Yale University Press, 1995. 


\section{Ethnic Studies Review Volume 23}

International Bank for Reconstruction and Development Report. World Development Report 1994: Infrastructure for Development. New York: Oxford University Press, 1994.

Jefremovas, Villia. "Acts of Human Kindness: 'Tutsi, Hutu and the Genocide" Issue 23 (1995), 28-31.

Koch, George. "The Cross." Saturday Night 111 (September 1996), 64-84.

Kuper, Leo. "The Pity of it All: Polarisation of Racial and Ethnic Relations. Minneapolis: University of Minnesota, 1977.

Kuper, Leo. Genocide: Its Political Use in The Twentieth Century. New Haven/London: Yale University Press, 1981.

Kupesinghe, Kumar and Valery A. Tishkov, eds. Ethnicity and Power in the Contemporary World. Tokyo/New York/Paris: United Nations University Press, 1996.

Lederer, Edith M. "Rwanda Genocide Blamed on U.N., U.S., France, Catholics." Arizona Daily Sun 54 (July 7, 2000), 8.

Lemarchand, Rene. Rwanda and Burundi. London:Pall, 1970

Lemarchand, Rene. "Burundi: The Killing Fields Revisited." Issue 18 (1989), 22-28.

Lemarchand, Rene. Burundi; Ethnocide as Dscourse and Practice. New York: Woodrow Wilson Center Press/Cambridge University Press, 1994.

Lemarchand, Rene. "Rwanda: The Rationality of Genocide." Issue 23 (1995), 8-11.

Linden, lan with Jane Linden. Church and Revolution in Rwanda. New York: Africana Publishing Co.,Manchester University Press, 1977.

Louis, W.M. Roger. Ruanda-Urundi: 1884-1919. Oxford:Clarendon Press, 1963.

Mackintosh, Anne. "Rwanda: Beyond 'Ethnic Conflict.' Development in Practice (November 1997), 464-474. 
Malkki, Liisa H. Purity and Exile: Violence, Memory, and National Cosmology among Hutu Refugees in Tanzania. Chicago/London: University of Chicago Press, 1995.

Mamdani, Mahmood. "From Conquest to Consent as the Basis of State Formation: Reflections on Rwanda." New Left Review 216 (March/April 1996), 3-36.

Maquet, Jacques J. The Premise of Inequality in Ruanda: A Study in a Central African Kingdom. London: International African Institute/Oxford University Press, 1961.

"Massacring the Truth in Rwanda." Living Marxism (December 1995), 24-27.

McAll, Christopher. Class, Ethnicity and Social Inequality. Montreal: McGill Queen's University Press, 1990.

Melady, Thomas Patrick. Burundi: The Tragic Years. New York: Orbis Books, 1974.

National Public Radio. All Things Considered, March 18, 1998.

Newbury, Catharine. "Background to Genocide: Rwanda.." Issue 23 (1995), 12-21.

Nsengiyumva, Francois Xavier. "Massacring Democracy in Rwanda." Freedom Review 25 (July 1994), 1-2.

Nutt, Dominic. "The Terror That is Burundi's Regroupment Camps." All Africa News Agency (March 3, 2000).

Olzak, Susan and Joane Nagel, eds. Competitive Ethnic Relations. Orlando: Academic Press, 1986.

Omamo, Steven Were. "Poverty, not Ethnicity, Drives Conflict in Zaire." The People 107 (May1997), 3, 11.

Oppenheim, Prof. J. "The Rwanda Crisis: Historical Background." Global Journal on Human Rights 2 (1997), 9-74.

Pruner, Gerard. The Rwanda Crisis: History of a Genocide. New York: Columbia University Press, 1995. "Rwanda: An American 
Ethnic Studies Review Volume 23

Empire?" Newsweek (December 2, 1996), 46.

U.S. Committee for Refugees. Life After Death: Suspicion and Reintegration in Post-Genocide Rwanda. Washington D.C.: U.S. Committee for Refugees, 1998.

Uvin, Peter. "Tragedy in Rwanda: The Political Ecology of Conflict." Environment 38 (April 1996), 7-15.

Van den Berghe, Pierre L. The Ethnic Phenomenon. New York/Oxford: Elsevier, 1981.

Weinstein, Warren and Robert Schire. Political Conflict and Ethnic Strategies: A Case Study of Burundi. New York: Syracuse University, 1976.

Winter, Roger P. Refugees in Uganda and Rwanda: The Banyarwandan Tragedy. Washington D.C.: U.S. Committee for Refugees, 1983. 